\title{
おいしい水と水源污染
}

\section{Good Taste Water and Sourse Water Pollution}

小島 貞 男*

最近デパートやスーパーマーケットに行くと瓶や紙 パックに詰めた水が売られている。そしてその種類は 50 種以上もあり，值段は $1 \ell 200$ 円から300円もしてい る.乙れは $1 \mathrm{~m}^{3} に$ 換算すると実に20万円〜30万円とな るから, 水道料金の $2,000 \sim 3,000$ 倍に当る.

またもう一つのブームは水道の蛇口に取り着ける家 庭用の浄水器で昨夏は乙れが異常な売行きだったとい う.

このような異常現象は何故起ったかというと, 近年 水道水がまずくなった，いや正確にいえば，まずくな った地域があるてとが一因である。そしてまずくなっ た原因は水源の污染（濁）にあると筆者は考えている.

つまり湖沼（ダム湖を含む）に污水が流入すれば， いわゆる富栄養化が起こり, その結果, 発臭性の藻類 (Phormidiumなど) や放線菌(Streptomycesなど) が増殖し，水にいやなカビ臭を着ける．そしてての カビ臭は通常の急速ろ過法では除去できないので水道 水がカビ臭くなる。

一方河川が都市排水などで污れると真先にアンモニ アが増加するが, てれが消毒用の塩素と化合して 3 塩 化窒素などを作り，いやなカルキ様の臭気を着ける。

と乙ろで水の扔いしさを大きく左右する条件には溶 存ミネラル量, 硬度, 炭酸・水温などがあるが, 日本 の水道水は,さいわいなととに水温以外は乙れらの条 件をすべて備えている．したがって冷蔵庫で冷やしさ えすれば，どての水道水でもおいしく飲むてとができ る.

ただし臭気てとにカビ臭のある水は例外で，冷やし ても, 沸かしても真のおいしい水にはならない.

その証拠には水のまずい都市へ行くと緑茶はむろん のとと紅茶であコーヒーであまずい.

また一諸に出されたアイスウォーターあロの中にし ばらく含んでいると臭気がわかる。

かつて琵琶湖のカビ臭が数年間発生しなかったとき
があるが，するとそれまで大いに売れていた浄水器の 売れゆきが急激に落ち込み，一社が倒産してしまった という話がある。つまりカビ臭が全く出なかったらて れほどまでに瓶詰め水も浄水器むブームにはならなか ったろうというのが私の考えである.

てのように考えると水道水を扔いしくするためには 一にあ二にあ水源の污濁を防ぐてとが肝要であるとい うことになるが，それでは水源污濁がなくなるまでは 他に全く手がないのであろうか.

水道水をおいしくするには, 湖沼（貯水池）水源に おいてカビ臭の発生を抑える方法と浄水場においてカ ビ臭を除去する方法とが考えられる。乙とに最近試み られている方法は速効性が期待できるばかりでなく, 経済的にも維持管理面であ優れているので今後もっと あ有望な対応手段であると考えられる.

ての方法は湖水を人工的に強制循環する方法である が，すでに30個所以上（その約半数はカビ臭対策）に 試み, いずれも好成績を収めている。

その原理は湖水を循環するととによって表層の藻類 プランクトンを光のない深層に移送し交互に明 $\rightarrow$ 暗 $\rightarrow$ 明 $\rightarrow$ 暗の環境を繰返すのである。

このようにすると藻類は光合成 $\rightarrow$ 分解消費 $\rightarrow$ 光合成

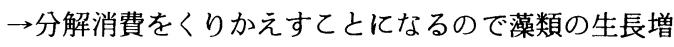
殖が抑えられるのである.

ことにカビ臭を出す藍藻類は暗所に弱いのか真先に 消滅するのでカビ臭の発生を抑制するてとができる.

ただての方法の弱点は浅い湖では効果が少ないてと と大容量の大湖では必要エネルギーが莫大で実用でき ないことである。

一方浄水場に扔いてカビ臭を削減または除去する方 法あいろいろと実用されているが，本題からはずれる ので省略する.

*(株) 日水コン 中央研究所所長 Sadao KOJIMA 